\title{
The Implementation of Peace and Security Programme initiative in Nigeria: The Role of NEPAD
}

\author{
Isaac Terungwa Terwase \\ Ghazali Shafie Graduate School of Government, College of Law, Government and International Studies, \\ Universiti Utara Malaysia, 06010 Sintok, Kedah, Malaysia \\ isaacterwase1@gmail.com
}

Asmat-Nizam Abdul-Talib

School of International Studies, College of Law, Government and International Studies, Universiti Utara Malaysia, 06010 Sintok Kedah, Malaysia

\section{Knocks Tapiwa Zengeni}

Knocks Tapiwa Zengeni, School of International Studies, College of Law, Government and International Studies, Universiti Utara Malaysia, 06010 Sintok Kedah, Malaysia

\section{Doi:10.5901/mjss.2015.v6n3p54}

\section{Abstract}

The New Partnership for Africa's Development (NEPAD) as an Agency of the African Union was established in 2001 by the African leaders with the view of eradicating poverty in Africa. The NEPAD programme initiatives encompasses the political, economic and social-cultural development of the African states through partnership with the private and public sectors, the international community and countries in and outside Africa. Through thematic areas of NEPAD such as, democracy and political governance has encompassed the peace and security programme initiative of NEPAD as a priority to be achieved. This then forms the objective of this paper to be studied considering the insecurity challenges that faced the Nigerian state as a member of the African Union and co-initiator of the NEPAD programme initiative. Since 2009, the Nigerian state is faced with the activities of the Boko Haram militant group whose engagement has led to activities such as burning and bombing of people's houses, churches, Mosques and public buildings, killing of innocent lives including but not limited to both Christians and Muslims, attack on security operatives and schools which include bombing of structures. This paper therefore, is to study the strategic plan of NEPAD in implementing the peace and security objective for the purpose of promoting peace and political stability in Nigeria. The methodology adopted in this research is the review of previous literature, the use of descriptive, historical, and interpretative methods of analysis, with the available research materials. The findings thus reveal that, issues such as zoning of political and elective positions should be addressed in the Nigerian constitution in order to accommodate the six geopolitical zones so as to promote unity, political stability, peace and security within the Nigerian state.

Keywords: NEPAD, Implementation, Nigeria, Peace and Security

\section{Introduction}

Africa like other continents of the world was colonized by the Europeans, and the colonization process took place in stages. In the Asian continent as well, many countries were colonized by the Europeans just as there was the presence of the British government in some of the countries such as Malaysia, India, and Singapore. Also, they were present in Australia and the New Zealand, as well as in North American countries like the United States of America and Canada. This is to establish that these continents also experienced colonization but today, they are far ahead of the African countries. This became a great concern for the African Union through her leadership to establish an agency charged with the functions and responsibility of repositioning Africa to the path of sustainable development through eradication of poverty. The African people who serve as great human resources are endowed with many natural resources in the said continent, but ironically, they still suffer from poverty.

This posed a major issue among others that brought the establishment of the New Partnership for Africa's Development (NEPAD) in 2001, by the leaders of the African Union (AU). NEPAD's establishment sought to reposition 
Africa looking at the issues that surrounds the continent from the political, economic, social and cultural points of view. As such, this programme stretches through Peace and Security, Education, Democracy, Good Political Governance, Economic and Corporate Governance, Agriculture, Environment, Energy, Water, Infrastructure, Transport, and Information and Communication Technology. In view of the fact that poverty is to be eradicated in Africa, there are certain issues that would be considered as well, which then forms the objectives of NEPAD programme as a policy document and framework. NEPAD therefore, seeks to integrate with the public sector, the private sector, civil society, the countries within and outside Africa, international organizations as well as the multinational companies in achieving her set goals and objectives (NEPAD, 2005).

However, can these objectives be achieved in the absence of Peace and Security? What then is the role of NEPAD in sustaining Peace and Security in African countries? In what ways can Peace and Security be sustained? These are the questions this research paper intends to focus on in proffering solutions and giving answers to the said questions. Many African countries in the past had gone through series of conflicts, insecurity challenges and wars. In the recent years in 2010 to 2014, we have issues such as the Arab spring in countries such as Tunisia, Egypt and Libya where the people wanted a change in government and the leadership of their countries. However, the focus of this paper is on Nigeria.

Terwase, Abdul-Talib and Zengeni (2014) observed in their work, the endowed resources in Nigeria as Africa's largest economy where there are natural and agricultural resources as well as human resources. Yet, with all the resources, the country is still faced with issues such as poverty and unemployment. Many of the Nigerian graduates are still searching for job opportunities, while in the rural areas the people are living in abject poverty especially in the villages, yet some of these villages have untapped resources. NEPAD therefore, seeks to partner with the developed countries, the emerging countries, private and public sectors in engineering production of raw materials into finished goods/products for the purpose of economic growth and development of the Nigerian state. According to some authors; poverty, unemployment, illiteracy and bad governance are the reasons that makes the youths to join groups that influenced them to engage in insurgency and to partake in militancy against the government such as the case of Boko Haram militant group in Nigeria (Dike, 2014; Olaiaya, 2014; Yusuf, 2013; Aghedo, 2012; Salaam, 2012; Jackson, 2007).

How then can the NEPAD programmes be implemented in the face of insecurity and absence of peace and security in Nigeria, especially in the Northern part of the country where there are a lot of activities of the insurgents group known as the Boko Haram, who started their attacks on the Nigerian State since 2009 during the administration of the Late President Umaru Musa Yar'Adua (Ekereke, 2013). The objective of this paper therefore, is to examine the role of NEPAD in implementing peace and security strategy in Nigeria. This will help us to understand the ways that NEPAD can get involved in restoring Peace and Security, as well as in conflict resolution. As a country, Nigeria has gone through series of insecurity challenges not only during the civil war, but also during the military administration, and the Niger Delta crisis during the civilian administration otherwise known as the period of democratic dispensation.

\section{Literature Review}

Gillies (2007) notes that, the Nigerian State known as the West African giant, has contributed in notable dimensions to the development of peace and security in the sub-region as well as to the African continent. In the past, the country through her leadership role in West Africa and indeed Africa, was able to deploy military forces to engage in the sustenance and maintenance of peace keeping operations in countries such as The Gambia, Guinea Bissau, Togo, Liberia, Cote d'Ivore, Darfur as well as Sao Tome and Principe.

In the work of Johnson (2007), it also discusses the role of Nigeria in contributing to the development of ECOWAS Monitoring Group (ECOMOG) through various roles in peace keeping especially in the conflict states in both sub-region and indeed African states. However, the work also associated insecurity challenges in Nigeria to poor leadership on the part of the government, issues surrounding unemployment of the youths, corruption, poverty, as well as religious conflicts. Such issues confront the country thereby leading to sources of insecurity in the country. Notwithstanding, the work is limited to knowledge in the area of NEPAD's role in resolving such conflicting issues that gives rise to insecurity challenges in Nigeria as a result of the Boko Haram activities which this paper intends to fill the gap.

Mangu (2014) reveals the achievements of the African Peer Review Mechanism (APRM) as well as that of the African Union in relation to political and legal perspective of NEPAD programme initiative on good political governance, and democracy in Africa. However, in the work of Bach (2013), it focuses on Africa with a broad view of understanding her relations with the states outside the African continent while presenting NEPAD to the global economy. NdlovuGatsheni (2012) concentrates on issues that affect the continent of Africa such as violence while revealing such issues in relation to pre-colonial, colonial, and post-colonial periods. The paper then establishes issues that affect the African 
countries, while same applies to Nigeria.

Mayaki (2010) then observes important issues that can lead to the development of African countries. He considers the opportunities that are in the continent which can be shared between the South-South countries through their experiences where the African continent can be developed rather than developing and establishing violence, crises, conflicts and war. This can be done through good leadership, good political governance with exchange of knowledge to push Africa forward. More has been written on Africa in relation to NEPAD's implementation of her programme initiative in areas such as political economy, democracy and political governance, but limited contribution to its programme implementation in the area of peace and security. This is the focus of this work, to give more understanding on the role of NEPAD in implementing peace and security, where political stability can be restored in the affected areas in Nigeria, especially in the Northern part of the country.

\section{The Role of NEPAD in Implementing Peace and Security Initiative}

The need for peace and security sustainability remains the backbone of human and societal existence, be it developed countries, developing countries or even underdeveloped countries, a harmonious environment is needed, where there is peace, security and political stability. For African countries to succeed or move forward an environment free of insecurity remains the first goal and that is the reason NEPAD has outlined her set goals where the said subject is listed first among other priorities (NEPAD, 2005).

Therefore, there are procedures that are followed in implementing the peace and security objective of NEPAD. The various bodies of NEPAD operate at country level where they are responsible for the implementation of the NEPAD programme initiatives. However, they report to the NEPAD Agency at their Headquarters in South Africa. NEPAD therefore serves as an Agency of the African Union who's Headquarters is located in Addis Ababa, Ethiopia. Issues relating to peace and security that could not be resolved at country level are therefore sent through the Head of the NEPAD Heads of State and Government Orientation Committee (HSGOC), who then sends such issues as recommendation to the African Union General Assembly for action and consideration (NEPAD HSGOC, 2014).

Indeed, African countries over the years wasted resources during the periods of war, political instability as a result of conflicts within some of the countries, while to some countries such resources are used for the development of people and government. AU/NEPAD (2009) reveals that, an estimated US\$18bn per year is what the continent spends on conflicts while her people are dying of poverty. Such resources can therefore be injected into the African economy to give hope to the poor, therefore fulfilling the very first primary objective of NEPAD as an Agency of the African Union, which is to eradicate poverty. NEPAD therefore, seeks to address peace and security initiative through the following areas:

A) Conflict prevention;

B) Conflict management;

C) Conflict resolution; and

D) Post-Conflict reconstruction.

In achieving this goal, NEPAD partners with the Federal Ministries, Departments and Agencies at the national level on how best issues relating to insecurity challenges can be resolved, other stakeholders of NEPAD includes the integration of the State and Local Governments, the Civil Society Organizations, the Private Sector, and as well as the international community to engage in strategies that would lead to conflict prevention, conflict management and resolution (NEPAD, 2001; NEPAD Nigeria, 2010 and NEPAD Nigeria, 2015). It is very important then to understand that without peace and security, the NEPAD objectives of partnering with other countries within and outside Africa becomes very difficult, and that is the major focus of this paper which is to proffer solutions to the issues that are presently facing Nigeria as a State in Africa, considering the insecurity challenges posed by the Boko Haram militants since 2009.

Many people have been killed during this period from 2009 to date (2015), issues such as suicide bombing have occurred in many states especially in the Northern part of the country such as Borno, Yobe, Adamawa, Kaduna, Kano, Plateau, Gombe, Bauchi, and Abuja which is the Federal Capital of Nigeria. Many innocent people have been killed during the attacks both on the people and government officials as well as the military officers. On the $14^{\text {th }}$ of April, 2014, many lives were killed in the Abuja bomb blast, some of whom were going to work that morning when the attack was launched on them. The mastermind of the said attack was later arrested in the Republic of Sudan by the International Police Organization (Interpol). Aminu Sadiq Ogwuche was brought back to Nigeria from Sudan after his arrest (Ajayi and Suberu, 2014). In a shocking revelation, Mr. Ogwuche confessed to have masterminded the Nyanya, Abuja bomb blast attack that killed over 70 people while answering questions posed by the Nigerian Security forces in Abuja. Ogwuche lamented more on their planned activities, of which some of it were in the past including that of Abuja attack. He also promised that they (Boko Haram militant group), are well prepared and well-funded to fight the Federal Government of 
Nigeria including the infidels.

Following the attack, the African Union condemned the attack on the people and government of Nigeria by the Boko Haram militants. The condemnation came through the AU Commission Chairperson in Addis Ababa, Ethiopia (Sotunde, 2014). According to the Premium Times (2014, May 17), the summit which was held in France hosted by the French President on the 17 $7^{\text {th }}$ of May, 2014, it was revealed that over 12,000 people have been killed by Boko Haram from their series of attacks on the people as it was made known by the President of Nigeria, Goodluck Jonathan during the summit in France.

Having seen some of the insecurity challenges as discussed above, it is then a serious issue which should be taken into account in order to put to an end to the looming conflict as it is spreading through other African countries such as Chad, Niger and Cameroon, as the group finds places of hideouts and collaborations. According to AU/NEPAD (2009) for the purpose of engaging in issues related to conflict in Africa countries and for such to be resolved, the highest body of the African Union known as the Assembly of Heads of State and Government established African Peace and Security Architecture (APSA) of the African Union on the $9^{\text {th }}$ July, 2002 Ordinary Session in Durban, South Africa. The APSA collaborates with the Regional Economic Communities such as Economic Community of West African State (ECOWAS), Southern African Development Community (SADC) in working relations to prevent conflict, engage in conflict resolution, and conflict management. The APSA therefore engages in peace monitoring, peace building as well as that of postconflict reconstruction.

\section{Recommendations}

The country Nigeria which is the largest economy in Africa is faced with insecurity challenges and is in a state of crisis especially in the Northern part, where some places are described as war zones. Such areas include Borno, Yobe and Adamawa states. These issues need to be resolved for the country to move forward. This paper therefore, recommends the following as suggestion to NEPAD, the government and people of Nigeria in resolving the crisis:

A) The Federal Government in collaboration with the National Assembly should amend the Nigerian constitution in order to accommodate the six geopolitical zones into the Nigerian constitution to create room for rotation of power sharing. This stands as the greatest problem the country is facing when it comes to the time and position of "who to rule" Nigeria, considering the diverse ethnic groups with over 300 languages in Nigeria and the issues of North and South divides as well as the religious backgrounds between the Christians and Muslims leadership of the country. The six geopolitical zones are recognized by the government but not recognized by the Nigerian constitution. What are the six geopolitical zones?

Below is an understanding of the said zones which includes the thirty-six states of the country Nigeria:

North-West zone constitutes of the following States namely Sokoto, Kano, Katsina, Zamfara, Kebbi, Kaduna and Jigawa.

North-East zone constitutes of Borno, Adamawa, Yobe, Taraba, Gombe and Bauchi States.

North-Central zone constitutes of Benue, Kogi, Nasarawa, Plateau, Niger and Kwara States.

South-West zone constitutes of Lagos, Ogun, Oyo, Osun, Ondo and Ekiti States.

South-East zone constitutes of Enugu, Anambra, Ebonyi, Abia and Imo States.

South-South zone constitutes of Rivers, Cross River, Akwa Ibom, Delta, Bayelsa and Edo States.

When the constitution of Nigeria makes provision for power rotation otherwise known as the Zoning Formula into the constitution, it will then give the opportunity for all the six geopolitical regions to participate fully in building peace, national unity, economic growth and development of the nation shall become the desire of all the regions. An example of this is sharing of power between the North and South rotationally within the zones respectively from term to term. Also, when a Muslim is the President from any of the zones in the North, then the Vice-President should be a Christian from any of the zones from the Southern part of the country. The seat of the President should rotate in all the zones before getting back to the zone that started out of the six zones. This would therefore resolve the problem of North and South power tussle, where the Christians and the Muslims fight over power as it is currently witnessed since the administration of President Goodluck Jonathan, which started from 2011 to 2015 as his first term after winning the 2011 presidential elections. Joseph (2014) notes that, a founding member of the People's Democratic Party (PDP), Mallam Adamu Ciroma lamented over the zoning issue as it was truncated by the PDP after the death of President Yar'Adua in 2010. It was no longer recognized by the PDP and as well as the Nigerian constitution and that became the source of political conflict therein.

It will also break the idea of using religion as a tool in fighting political issues and interests in the name of fight between the Muslims and Christians just like what is happening since Jonathan took over as the president. The Boko 
Haram in one of their videos lamented the reasons why they are fighting the Nigerian government is that they are against the Nigerian constitution and Democracy. It will also resolve the problem of neglecting other sections of the country in occupying the seat of the President like the South-East zone, where the Igbos have not been allowed to be President since the end of the Nigeria civil war in 1970. This led to the intention of the Igbos to disintegrate from Nigeria to establish her own country. Also, the neglect of the North-Central where it seems as if a Northern Christian cannot be the President of Nigeria in a democratic dispensation, since the major ethnic group in the Northern part of the country amongst other groups is that of the Hausa-Fulanis from the North-West and North-East zones and majority of them are Muslims in the North. The truncated zoning arrangement by the PDP in 2010 after the President Yar'Adua's death has amounted to Christian/Southern leadership of the country from 1999-2007 and 2010-2015 under study. Thus, zoning is not recognized by the Nigerian constitution and it connotes the idea of why the Boko Haram insurgents are fighting against the Nigerian state, the Nigerian constitution and democracy. When this issue is resolved within the Nigerian constitution, it will then provide an environment for equity, peace, political stability and unity in diversity.

B) The government of Nigeria should fight corruption to a zero level and should provide autonomy to the anticorruption agencies, like the Economic and Financial Crime Commission (EFCC) to do their work without any interference from the Federal Government especially the Presidency. Public money that has been made away by public officers in office should be brought back into the Federal Government treasury for the purpose of developing the country.

C) Provision of job opportunities for the youths who have graduated from higher institutions of learning. This will enable them to be productive as well as to be engaging in doing something meaningful to contribute to the growth and development of the country. Most of the Boko Haram members are jobless youths who become tools in the hands of the militants where they serve as members of the militant group.

D) Provision and enhancement of education facilities from primary to higher levels of education in Nigeria. Sponsorships should be provided to excelling and deprived students to encourage scholarship. More so, the teachers and lecturers should be paid promptly when due rather than allowing them to embark on incessant strikes which cripple the educational system.

E) NEPAD should embark on serious sensitization in collaboration with the civil society organizations, governments at all levels, non-governmental organizations, as well as the private sector in launching Peace and security awareness campaigns, the need for peace and conflict resolution between the government and the people. NEPAD should therefore, strategize in resolving the conflict using the above suggestions as recommendations to the federal government as well as the African Union, as one of the means to ending the conflict.

F) The people of Nigeria also have a role to play. They must accord high regard to Nigeria before attending to personal interests. No country can stand when it is divided against her-self. United we stand as a country, but divided we fall as a people and country. Nigerians as a people must understand that, there is strength and unity in diversity, therefore, the differences arising from ethnic and cultural backgrounds should be rather translated into a source of strength, where nation building can be sustained, then peace and political stability can be restored.

\section{Conclusion}

Nigeria is an endowed country with diverse natural resources, and the highest population in Africa. The country's population therefore serves as a huge market and resource base both locally and internationally. As a backbone of the West African sub-region, the country has contributed to the development of many countries in Africa especially countries that passed through crisis at some point. Also in the past, her military power was used in restoring peace and security in such countries as Liberia, The Gambia, Guinea Bissau, Togo, Cote d'Ivore, Darfur and Sao Tome and Principe. Nigeria serves as the Headquarters of the ECOWAS, a major power and contributor to ECOWAS Monitoring Group (ECOMOG) during the peace keeping operations in many African countries. This provides a basis for the need for peace and security to be restored in Nigeria, and for the people to be united. NEPAD, therefore in collaboration with the African Union and other relevant bodies should engage in conflict resolution processes using the mediation tool between the Boko Haram and the Nigerian government in order to resolve the issues therein for the purpose of enhancing political stability.

The zoning formula should be applied for the purpose of creating an environment where all the zones will be recognized in the Nigerian constitution so as to ensure power rotation among the six geopolitical regions of the country Nigeria. This would help bring the people together where unity shall be restored between the Christians and the Muslims, the North and the South. The government should provide more jobs for the youths and the educational system should be 
improved and monitored. All these if effectively done, would enhance nation building, economic growth and development of the people and the country.

\section{References}

Aghedo, I. (2012) Winning the War, Losing the Peace: Amnesty and the Challenges of Post- Conflict Peace-Building in the Niger Delta, Nigeria, Journal of Asian and African Studies, 48(3), 267-280, DOI: 10.1177/0021909612453987

Ajayi, O., and Suberu, F. (2014) Interpol Extradites Abuja Bomb Blast Mastermind, Ogwuche, Retrieved from http://nationalmirroronline. net/new/interpol-extradites- abuja-bomb-blast-mastermind-ogwuche/

AU/NEPAD, (2009) The AU/NEPAD African Action Plan 2010-2015: Advancing Regional and Continental Integration in Africa, Retrieved from http://www.uneca.org/sites/ default/files/uploads/sectors.pdf

Bach, D. C. (2013). Africa in International Relations: The frontier as concept and Metaphor, South Africa Journal of International Affairs, 20:1, 1-22, DO10.1080/10220461.2013. 783283

Dike, V. E. (2014) Leadership and the Nigerian Economy, Sage Open, January-March, 1-10, DOI: 10.1177/2158244014523792

Ekereke, A. S. (2013). The Effects of Boko Haram Insurgency and the School System: A case study of Selected States in Northern Nigeria, Science Journal of Sociology and Anthropology, DOI: 10.7237/sjsa/137

Gillies, A. (2007) Obasanjo, the Donor Community and Reform Implementation in Nigeria, the Round Table: The Commonwealth Journal of International Affairs, 96:392, 569-586, DOI: 10.1080/00358530701625992

Jackson, A. (2007). Nigeria: A Security Overview, The Round Table: The Commonwealth Journal of International Affairs 96: 392, 587603, DOI: 10.1080/00358530701626040

Joseph, M. (2014) Obasanjo Destroyed Zoning Agreement - Adamu Ciroma, Retrieved from, http://leadership.ng/news/380561/ obasanjo-destroyed-zoning-agreement-adamu-ciroma

Mangu, A. M. (2014). The African Union and the Promotion of Democracy and Good Political Governance under the African PeerReview Mechanism: 10 years on, Africa Review, 6:1, 59-72, DOI: 10.1080/09744053.2014.883757

Mayaki, I. A. (2010 South-South Mutual Learning: A Priority for National Capacity Development in Africa, Retrieved from http://siteresources. worldbank.org/WBI/Resources/213798-1286217829056/mayaki.pdf

National Mirror, (2014) A Picture showing The Abuja Bomb blast Mastermind and the Interpol, Retrieved from http://nationalmirroronline. net/new/interpol-extradites-abuja-bomb-blast-mastermind-ogwuche/

Ndlovu-Gatsheni, S. J., (2012). Beyond the Equator There Are No Sins: Coloniality and Violence in Africa, Journal of Developing Societies, 28: 41, DOI:10.1177/0169796X12463143

NEPAD HSGOC, (2014). NEPAD Heads of State and Government Orientation Committee (HSGOC), Retrieved from http://www.nepad. org/hsgoc-0

NEPAD Nigeria, (2010) Nigeria Governance and Development: The New Partnership for Africa's Development, Caligata Publishing Company Limited, Ibadan, Nigeria

NEPAD Nigeria, (2014) Principles and Values, Retrievedfromhttp://www.nepadaprm.gov.ng/homepdf/PRINCIPLES\%20AND\%20 VALUES.pdf

NEPAD Nigeria, (2015) NEPAD Current Focus, Retrieved from http://nepad.gov.ng/index.php/about-us/about-nepad/11-about-us/81current-focus

NEPAD, (2001) The New Partnership for Africa's Development, PinPoint Prints, Abuja

NEPAD, (2005) A Programme of the African Union, African Union Commission, Ethiopia

Olaiya, T. A. (2014) Youth and Ethnic Movements and Their Impacts on Party Politics in ECOWAS Member States, Sage Open, January-March, 1-12, DOI: 10.1177/2158244014522072

Premium Times, (2014, May 17) Boko Haram Has Killed Over 12,000 Nigerians, Plans to Take over Country, Jonathan Says, Retrieved from http://www.premiumtimesng.com/news/160942-boko-haram-killed-12000-nigerians-plans-take-country-jonathan-says.html

Salaam, A. O. (2012) Boko Haram: beyond religious fanaticism, Journal of Policing, Intelligence and Counter Terrorism, 7:2, 147-162, DOI: $10.1080 / 18335330.2012 .719096$

Sotunde, A., (2014). A Picture Showing the Public Buses that were bombed in Abuja, Retrieved from http://www.peaceau.org/en/ article/the-african-union-strongly-condemns-the-terrorist-attack-in-abuja

Terwase, I. T., Abdul-Talib, A. N., Zengeni, K. T. (2014) Nigeria, Africa's Largest Economy: International Business Perspective, International Journal of Management Sciences, Vol 3, No. 7, page 534-543

The Trent, (2014, July 22) 'I enjoy killing people': Chilling Confession of Nyanya Bombing Mastermind, Retrieved from http://www.thetrentonline.com/enjoy-killing-people-chilling-confession-nyanya-bombing-mastermind-pictured/

Yusuf, H. O. (2013) Harvest of violence: the neglect of basic rights and the Boko Haram insurgency in Nigeria, Critical Studies on Terrorism, 6:3, 371-391, DOI: 10.1080/17539153.2013.835528 